\title{
Protestant and Catholic Medicine in the Sixteenth Century? The Case of Ingolstadt Anatomy
}

\author{
JÜRGEN HELM*
}

There is an ongoing debate about the relation between religious confession and sixteenth-century medicine. Although it is generally agreed that Richard Toellner's statement "In Wittenberg the Reformation does not affect the medical faculty", which closes a paper published in $1984,{ }^{1}$ cannot be maintained in this apodictic formulation, recent research still discusses how and to what extent confessional matters might have influenced sixteenth-century medical thinking. Interest has focused in particular on the "anatomical Renaissance", as Andrew Cunningham's book is entitled, ${ }^{2}$ which reviewed the works of Andreas Vesalius (1514-1564) and several sixteenth-century anatomists as well as the dissemination of their ideas celebrated by generations of medical historians as the beginning of modern anatomical research.

In his paper on 'Wittenberg anatomy' Vivian Nutton showed in 1994 that a special view of anatomical knowledge was taken at Wittenberg University. ${ }^{3}$ According to Nutton, Wittenberg anatomy must be considered as an "education process in which a variety of messages was transmitted" to the students. ${ }^{4}$ Here, at the Leucorea, the heart of Lutheran Reformation, anatomy was focused on its theological implications: it dealt particularly with the links between the body and the Christian soul and hence affected Christian morality. Furthermore, anatomy, the disclosure of the wonderful structure of the human body, was most suitable for demonstrating the Creator's skill in designing nature. Philipp Melanchthon's (1497-1560) Commentarius

Jürgen Helm, Dr med., Martin-LutherUniversität Halle-Wittenberg, Institut für Geschichte und Ethik der Medizin, Magdeburger Straße 27, D-06097 Halle/Saale, Germany.

I should like to thank the staff of the Department "Alte Drucke" in the University Library of Munich for making available the sixteenthcentury literature. I am also indebted to Corinna Killermann, MA, and to Dr Kenneth Appold for reading and correcting earlier versions of this paper.

${ }^{1}$ Richard Toellner, 'Die medizinischen Fakultäten unter dem Einfluß der Reformation', in A Buck (ed.), Renaissance-Reformation. Gegensätze und Gemeinsamkeiten, Wiesbaden, Harrassowitz, 1984, pp. 287-97, on p. 297: “In Wittenberg findet ein Einfluß der Reformation auf die Medizinische Fakultät nicht statt."

${ }^{2}$ Andrew Cunningham, The anatomical Renaissance: the resurrection of the anatomical projects of the ancients, Aldershot, Scolar Press, 1997.

${ }^{3}$ Vivian Nutton, 'Wittenberg anatomy', in O P Grell and A Cunningham (eds), Medicine and the Reformation, London, Routledge, 1993, pp. 11-32.

${ }^{4}$ Ibid., p. 16. 
de anima, ${ }^{5}$ later published as Liber de anima, ${ }^{6}$ contributed-as Nutton writes-to the spread of a "coherent message of Lutheran anatomists", ${ }^{7}$ which was taught in the medical faculty as well as in the faculty of arts, therefore gaining importance for all students, not only for the few training to be physicians. One striking feature of Wittenberg anatomy was its willingness to adopt the most recent anatomical knowledge, represented by the Greek Galen and-in the Liber de anima-by Andreas Vesalius. As Nutton concludes, at Wittenberg the struggle between convinced Galenists and the adherents of Vesalius was secondary to the theological connotations of knowledge about the human body. ${ }^{8}$ Moreover, the dissemination of this Lutheran anatomy did not stop at the borders of Wittenberg. It was also taught at Protestant universities like Jena or Greifswald. ${ }^{9}$

But, as a close reading shows, Nutton's paper does not define what is specifically "Lutheran" in Wittenberg anatomy. This gap can be filled in in the light of the results published by Sachiko Kusukawa and Günter Frank in their books on Melanchthon's theological philosophy. ${ }^{10}$ The junction between anatomical education and Lutheran theology depends on the Lutheran distinction between gospel and law. In general, anatomy was considered part of the law. Strictly speaking, it was part of Protestant anthropology explaining the human condition after the fall of man and elucidating man's fundamental sinfulness and his need for salvation. Anatomy was also part of Melanchthon's natural philosophy confirming the providence of God by contemplating his skilful creation. This "Lutheran" pattern of anatomical education explains why anatomy was held in high esteem at Wittenberg University. ${ }^{11}$

The influence of religious confession on anatomy has also been investigated by Roger French and Andrew Cunningham. Their results are not restricted to anatomical education, but cover the whole area of sixteenth-century anatomy. Roger French, for example, suggests in at least two of his papers ${ }^{12}$ that the adoption of Vesalius' anatomical findings was primarily a matter of confession: "By the end of the sixteenth century, anatomy had split up into groups over the Vesalius affair. Many Catholics wanted to defend Galen and the learned tradition in general", while a "number of

\footnotetext{
${ }^{5}$ Philipp Melanchthon, Commentarius de anima, Wittenberg, Seitz, 1540 (VD 16, M 2749).

${ }^{6}$ Philipp Melanchthon, Liber de anima, recognitus ab Autore, Wittenberg, Seitz, 1553 (VD 16, M 2757). This text was reprinted in Carl Gottlieb Bretschneider and Heinrich Bindseil (eds), Corpus Reformatorum. Philippi Melanthonis opera quae supersunt omnia, Halle and Brunswick, Schwetschke, 1834-1860, vol. 13 (=CR 13), col. 5-178, see CR 13, col. 1-2. Sixteenth-century printings of Melanchthon's De anima are listed in Hermann Schüling, Bibliographie der psychologischen Drucke des 16. Jahrhunderts, Hildesheim, Olms, 1967, pp. 183-6.

${ }^{7}$ Nutton, op. cit., note 3 above, p. 12.

${ }^{8}$ Ibid., p. 17.

${ }^{9}$ Ibid., p. 25.

${ }^{10}$ Sachiko Kusukawa, The transformation of natural philosophy: the case of Philip
}

Melanchthon, Cambridge University Press, 1995. Günter Frank, Die theologische Philosophie Philipp Melanchthons (1497-1560), Leipzig, Benno, 1995.

${ }^{11}$ For more detailed information on this topic, see Jürgen Helm, " "Medicinam aspernari impietas est"-Zum Verhältnis von Reformation und Medizin in Wittenberg', Sudhoffs Archiv, 1999, 83: 22-41.

${ }^{12}$ Roger K French, 'Natural philosophy and anatomy', in J Céard, M M Fontine, and J-C Margolin (eds), Le corps à la Renaissance. Actes du XXXe colloque de Tours 1987, Paris, Amateurs de Livres, 1990, pp. 447-60. Idem, 'The anatomical tradition', in W F Bynum and R Porter (eds), Companion encyclopedia of the history of medicine, London and New York, Routledge, 1993, vol. 1, pp. 81-101. 


\section{The Case of Ingolstadt Anatomy}

Protestants took the line that the individual's own duty to order his knowledge of God meant that authority had to be given to personal observation."13 Andrew Cunningham goes one step further than French and assumes that Vesalius himself was a Lutheran, because "his work in anatomical reform [was] replicating precisely Luther's work in religious reform". ${ }^{14}$

In the light of these latest claims by medical historians, the investigation of a German Catholic university seems to be overdue. By comparing Wittenberg anatomy with the anatomical education at a Catholic university in the second half of the sixteenth century, we will be able to find similarities and differences and to analyse the specific and perhaps confessionally influenced approach to the human body. Are there, in the sphere of sixteenth-century Catholicism, any theological motives for reading anatomical books or for anatomizing human bodies? And what about the adoption of new anatomical findings? Were Catholics per se more conservative and less willing than Protestants to accept Vesalius' corrections of Galen's anatomy? And finally, was Vesalius himself perceived as a Lutheran by Catholic anatomical teachers?

The present paper deals with the University of Ingolstadt. In the first part this is presented as a sixteenth-century Catholic university. The second describes the anatomical education at Ingolstadt, and the third presents a rather unexpected find from the University Library of Munich.

\section{The Catholic University of Ingolstadt}

In the middle of the sixteenth century the universities of the Empire split according to confession. ${ }^{15}$ In the Catholic camp the Bavarian University of Ingolstadt proved to be a bastion against the Wittenberg Reformation during the whole of the century and beyond. But considering the university's history in the late fifteenth and the early sixteenth century, there are more similarities than differences in comparison with the Saxon University of Wittenberg. ${ }^{16}$ Founded in 1472 as a typical late-medieval university by the Duke of Bavaria-Landshut, the University of Ingolstadt went through a series of humanist reforms beginning in the second decade of the sixteenth century ${ }^{17}$ and

\footnotetext{
${ }^{13}$ Ibid., p. 88 .

${ }^{14}$ Cunningham, op. cit., note 2 above, $\mathrm{pp}$. 234-5. A further point of view is maintained by Andrew Wear, who talks of interactions between Christian religion and anatomy, but does not distlnguish between specifically Catholic and Protestant views on anatomical matters. See Andrew Wear, 'Medicine in early modern Europe, 1500-1700', in L I Conrad, M Neve, V Nutton, $\mathrm{R}$ Porter, A Wear, The western medical tradition: 800 BC to $A D$ 1800, Cambridge University Press, 1995, pp. 215-361, on pp. 287-9.

${ }^{15}$ See, for example, Arno Seifert, 'Das höhere Schulwesen. Universitäten und Gymnasien', in N Hammerstein (ed), Handbuch der deutschen Bildungsgeschichte, Band I, 15. bis 17. Jahrhundert. Von der Renaissance und der Reformation bis zum Ende der Glaubenskämpfe,
}

Munich, Beck, 1996, pp. 197-374, on pp. 282-92, 312-29.

${ }^{16}$ For the history of the University of Ingolstadt, see Carl Prantl, Geschichte der Ludwig-Maximilians-Universität in Ingolstadt, Landshut, München, 2 vols., Munich, Kaiser, 1872, and for Wittenberg, Walter Friedensburg, Geschichte der Universität Wittenberg, Halle, Niemeyer, 1917.

${ }^{17}$ See Hannelore Hradil, 'Der Humanismus an der Universität Ingolstadt (1477-1585)', in L Boehm and J Spörl (eds), Die LudwigMaximilians-Universität in ihren Fakultäten, 2 vols, Berlin, Duncker \& Humblot, 1980, vol. 2, pp. 37-63, on pp. 47-52, and Albrecht Liess, 'Die artistische Fakultät der Universität Ingolstadt 1472-1588', in ibid., vol. 2, pp. 9-35, on pp. 22-9. 


\section{Jürgen Helm}

experienced - just as Wittenberg - a crisis in the third decade. ${ }^{18}$ Like Wittenberg, Martin Luther's (1483-1546) academic home, Ingolstadt was involved in the Reformation from the very beginning: Johannes Eck (1486-1543), who had been appointed to a chair of theology in 1510, was Luther's strongest opponent in the orthodox camp. His vehement and acrimonius defence of the old faith, presented at Imperial Diets and religious disputes and strengthened by a great number of writings, moulded the character of the University of Ingolstadt for the next century. ${ }^{19}$ In 1550 , the Bavarian Duke Albrecht V felt justified in writing to Pope Julius III, that his University had been particularly firm "in sowing and planting the Catholic faith and the orthodox doctrine". ${ }^{20}$

This strict confessional orientation of Ingolstadt University left its traces on the careers of several sixteenth-century graduates. The best known of them is Leonhart Fuchs (1501-1566), who left Ingolstadt twice for religious reasons before finally being appointed to a chair at the Protestant University of Tübingen. ${ }^{21}$ Veit Amerbach's (1503-1557) case was the exact opposite: he left Wittenberg because of irreconcilable theological differences with Luther and Melanchthon and made his career in Ingolstadt from 1543. ${ }^{22}$ Less well known are Martin Hofmann (died after 1598), who attained his doctorate in 1555 , and lectured for one year at the medical faculty in Ingolstadt, ${ }^{23}$ and the Wittenberg master Johannes Vischer (1524-1587), who was professor at Ingolstadt for scarcely a year. Like Hofmann he left the university because of religious disagreements. After working as municipal physician in Nördlingen and as the personal physician of Georg-Friedrich of Brandenburg-Ansbach at the court of Ansbach, Vischer finally succeeded Leonhart Fuchs in Tübingen. ${ }^{24}$

In 1568 , the situation came to a head. According to a papal instruction, the professio fidei tridentini was demanded of all graduates at Ingolstadt. ${ }^{25}$ As a consequence, Philipp Apian (1531-1589) was no longer permitted to teach in the arts faculty because he refused the oath. ${ }^{26}$ Two years earlier his appointment to a medical chair failed because of Johann Ammonius Agricola's (1488-1570) resistance; Agricola had suspected Apian of being a Lutheran. ${ }^{27}$ Apian was unlucky as well later, in

\footnotetext{
${ }^{18}$ See Prantl, op. cit., note 16 above, vol. 1, p. 164 , and Friedensburg, op. cit., note 16 above, pp. 157-9.

${ }_{19}$ For a brief sketch of Eck's life and work, see Manfred Weitlauff, 'Eck, Johannes', in L Boehm, W Müller, W J Smolka, and H Zedelmaier (eds), Biographisches Lexikon der Ludwig-Maximilians-Universität München, Teil I, Ingolstadt-Landshut 1472-1826, Berlin, Duncker \& Humblot, 1998, pp. 88-91.

${ }^{20}$ Quotation taken from Seifert, op. cit., note 15 above, p. 313.

${ }^{21}$ About Fuchs, see Eberhard Stübler, Leonhart Fuchs. Leben und Werk, Munich, Drucke, 1928, and (with detailed bibliographical information) Fritz Krafft, 'Fuchs, Leonhart', in Boehm, Müller, Smolka, and Zedelmaier (eds), op. cit., note 19 above, pp. 135-42.

${ }_{22}$ See Helmut Flachenecker, 'Amerbach, Veit', in Boehm, Müller, Smolka, and Zedelmaier (eds), op. cit., note 19 above, pp. 10-11, and Günter Frank, 'Veit Amerbach (1503-1557). Von
}

Wittenberg nach Ingolstadt', in H Scheible (ed.), Melanchthon in seinen Schülern, Wiesbaden, Harrassowitz, 1997, pp. 103-28.

${ }^{23}$ See Leonore Liess, Geschichte der medizinischen Fakultät in Ingolstadt von 1472 bis 1600, Munich, Demeter, 1984, p. 137.

${ }^{24}$ Ibid., pp. 136-7, and Rainer A Müller, 'Vischer, Johannes', in Boehm, Müller, Smolka, and Zedelmaier (eds), op. cit., note 19 above, p. 456.

${ }^{25}$ See Prantl, op. cit., note 16 above, pp. 269-73, and L Liess, op. cit., note 23 above, p. 104.

${ }^{26}$ About Philipp Apian, see Christoph Schöner, 'Apian, Philipp', in Boehm, Müller, Smolka, and Zedelmaier (eds), op. cit., note 19 above, pp. 16-18.

${ }^{27}$ See Christoph Schöner, Mathematik und Astronomie an der Universität Ingolstadt im 15. und 16. Jahrhundert, Berlin, Duncker \& Humblot, 1994, pp. 428-9. 


\section{The Case of Ingolstadt Anatomy}

Tübingen: in 1582 he opposed the Formula of Concord and lost a chair of mathematics for the second time. On the other hand, Georg Palma (1543-1591), a student at Wittenberg, Tübingen and Padua, attained his medical doctorate in 1568 at Ingolstadt without pledging allegiance to the Tridentinum, after the medical faculty was granted an exemption by the Duke and the University. ${ }^{28}$ In the same year, Esaias Han was awarded his medical degree. After seven years in Tübingen he had moved to Ingolstadt for his doctorate, because-according to the matricula-he preferred to receive the doctorship "apud orthodoxos et catholicos". ${ }^{29}$

There is another reason why the second half of the sixteenth century was crucial for the confessional orientation of the University of Ingolstadt. ${ }^{30}$ As early as 1549 , a member of the Society of Jesus, Petrus Canisius (1521-1597), was appointed to a professorship in theology, holding the chair until $1552 .{ }^{31}$ Four years later, in 1556, Duke Albrecht V founded at his own expense the Jesuit College at Ingolstadt, and in 1558 two professorships in theology out of four were awarded to the Jesuits. In accordance with the Society's programme, lectureships in the arts faculty were transferred to Jesuits during the next twelve years, until the Society succeeded in establishing its whole Cursus philosophicus in 1570. A few months later, a ducal order made participation in the Cursus obligatory for everybody aspiring to the Master of Arts. In 1572, all medical students and students of theology were obliged to attend the Cursus as well. These instructions met with the violent resistance of the University. As a result, the Jesuits moved their Cursus and the Paedagogium to Munich in 1573. During the following year, however, the University and the government failed to fill the gap left by the Jesuit professors, lecturers and the Paedagogium, so that their return was discussed as early as 1574 . In 1576, the Society came back to Ingolstadt, re-establishing the Paedagogium and the Cursus philosophicus, which became again obligatory for those studying to be Masters of Arts. In the beginning, the University was successful in keeping secular professorships in addition to the Jesuit lecturers, but these professorships were cancelled one after the other by the Duke, so that in 1588 , the whole arts faculty was formally transferred to the Society.

The University's struggle for autonomy in the early seventies has left behind literary traces. In 1571, one year before the University's centenary, Valentin Rotmar, who had just been appointed to a chair of rhetoric, published a collection of orations given by professors and doctors at Ingolstadt during the previous years. ${ }^{32}$ This volume, which was dedicated to Duke Albrecht V, was aimed at proving the University's academic performance and its rich tradition. ${ }^{33}$ Possibly for the same reason, the four faculties printed a voluminous catalogue of lectures in the same

\footnotetext{
${ }^{28}$ See L Liess, op. cit., note 23 above, pp. 178-9, and Prantl, op. cit, note 16 above, p. 271.

${ }^{29} \mathrm{~L}$ Liess, op. cit., note 23 above, p. 180.

${ }^{30}$ For this paragraph, see A Liess, op. cit., note 17 above, pp. 26-33, and Arno Seifert, 'Die jesuitische Reform', in Boehm and Spörl (eds), op. cit., note 17 above, pp. 65-89, on pp. 65-73.

${ }^{31}$ Engelbert M Buxbaum, 'Canisius, Petrus', in Boehm, Müller, Smolka, and Zedelmaier (eds), op. cit., note 19 above, pp. 60-2.
}

\footnotetext{
${ }^{32}$ Valentin Rotmar (ed.), Tomus primus orationum Ingolstadiensium, in quo gravissimae \& utilissimae, omnium facultatum materiae, suis quaeque distinctae partibus, continentur, a clarissimis \& doctissimis eiusdem Academiae Professoribus, aliisque eruditis viris partim scriptae, partim ab ipsis vel aliis recitatae, Ingolstadt, Weissenhorn, 1571 (VD 16, R 3361), UB Munich $8^{\circ}$ Rhet. 224.

${ }^{33}$ See Hradil, op. cit., note 17 above, p. 57.
} 


\section{Jürgen Helm}

year. ${ }^{34}$ These documents, Rotmar's volume and the printed programmes of the faculties, are important sources for the education undertaken at the University in the second half of the sixteenth century.

To sum up, there is no doubt that the University of Ingolstadt can serve as a contrasting model to the Protestant University of Wittenberg. The Bavarian university was involved in theological disputes from the very beginning, its members not only had to teach but also had to prove their orthodox faith, and in the second half of the century the confessional orientation of the institution became even stronger, culminating in the takeover of the arts faculty by the Society of Jesus. What, then, can be said about anatomy taught at this thoroughly Catholic University?

\section{Anatomy at Ingolstadt}

In the first half of the sixteenth century, there is only little evidence of periodically performed dissections and a regular anatomical education at Ingolstadt. It is true that in 1507 the medical professors advised the Duke to provide for the delivery of human bodies to the faculty ${ }^{35}$ and in 1522 , a building "ad celebrandam anathomiam" is mentioned in the University records, ${ }^{36}$ but these are the only references to anatomy up to 1555 . We do not know how often dissections took place at Ingolstadt and-what is more important here-we do not know what kind of anatomical literature was read within the medical curriculum.

We are much better informed about the second half of the century. In 1555 the visitation report of a ducal committee, which did not flatter the faculty, resulted in a ducal order that the medical students should be educated both theoretically and practically. The professors were admonished to present their patients to the students and to perform anatomical dissections of male and female human bodies periodically. ${ }^{37}$ The mention of anatomizing in this context suggests that such dissections were not usually performed at this time. Nevertheless, the ducal message was partly heard, as is proved by a sentence explaining the curriculum, which was probably written at the end of the fifties and sent to the University of Freiburg several years later. ${ }^{38}$ "Non enim imaginaria est philosophia, sed autopsiam vel autaisthesin desiderat medicina": "Philosophy is not a matter of imagination, but medicine needs autopsy or self-perception", and for this reason-as the curriculum says-a skeleton should be obtained for teaching the osseous structure. This sounds Vesalian, but in fact the passage ends with a strong reference to Galen. He has-as the text goes on-

\footnotetext{
${ }^{34}$ The programme is printed in extracts in Arno Seifert, Die Universität Ingolstadt im 15. und 16. Jahrhundert. Texte und Regesten, Berlin, Duncker \& Humblot, 1973, pp. 259-69. The programme of the medical faculty is completely printed in L Liess, op. cit, note 23 above, pp. 298-304.

${ }^{35}$ L Liess, op. cit., note 23 above, pp. 61-2.

${ }^{36}$ Ibid., pp. 69 and 282.

${ }^{37}$ Ibid., pp. 284: "Sy [the medical professors] sollen verrer, so offt mans gelegentlich bekhommen mag, anathomias fürnemen und in
}

dem allen den auditoribus tam universali quam particulari virilis et muliebris corporis anathomia einen augenscheinlichen gutten bericht thun. Do es auch on beschwerung der patienten beschechen khan, sollen sy die auditores zu zeiten mitt füeren und also die practic neben der theorie lernen." See ibid., pp. 76-7.

${ }^{38}$ About this curriculum, see Ernst Theodor Nauck, 'Der Ingolstädter medizinische Lehrplan aus der Mitte des 16. Jahrhunderts', Sudhoffs Archiv, 1956, 40: 1-15, and L Liess, op. cit., note 23 above, pp. 77-86. 


\section{The Case of Ingolstadt Anatomy}

principally condemned the idle, inconsistent and harmful opinions based on Aristotelian philosophy, which should not be taught by the professors. ${ }^{39}$

In general, this curriculum, which was probably written between 1556 and $1560,{ }^{40} \mathrm{can}$ serve as a model for sixteenth-century Hippocratism and Galenism. In the text Galen himself is called "docendi atque discendi praestantissimus magister" ("the most excellent master of teaching and learning"). ${ }^{41}$ Hence, the curriculum lists more than 120 writings by Hippocrates and Galen as set texts to be read by medical students. It seems clear that this catalogue of works reflects the ideal concept of a humanist physician rather than the reality of medical education, but what is striking is the fact that for the author of the curriculum, presumably Johann Ammonius Agricola, there was obviously no contradiction between Galenism and personal observation..$^{42}$ Consequently, the skeleton mentioned in the curriculum was bought for the faculty in 1564 by Ammonius, ${ }^{43}$ who not only in the catalogue, but also in his writings, was a convinced Galenist. ${ }^{44}$

A somewhat different picture emerges from the catalogue of lectures printed in 1571 . A whole chapter is devoted to anatomical education, ${ }^{45}$ in which the need for sensual perception is emphasized. In this context the now existing skeleton is pointed out because it could help to understand the connection of the bones and the course of the muscles. Moreover, the practical skill as well as the theoretical knowledge of the anatomists is dealt with: dissection is called "corporis humani pulcherrimae fabricae orthotomia" ("the accurate cutting of the most beautiful fabric of the human body"), and it is to be performed not by barbers, but by the professors themselves, who alone are able to show the students "exactissime" ("very exactly") the appearance, texture, location, size, substance, and the connections of the single parts. ${ }^{46}$ This passage is more than a vague allusion to Vesalius. Although no anatomical author is explicitly mentioned in the catalogue, we may conclude that Vesalius' De humani corporis fabrica libri septem form the background to this chapter on anatomical education.

This assumption is confirmed by the writings of the two professors teaching at the medical faculty in 1571, who were responsible for the catalogue of medical lectures. Both of them, Adam Landau (died 1573) and Johann Lonaeus Boscius (1515-1585), praise Vesalius lavishly in their publications. Boscius, for example, writes in his 'Oratio de optimo medico \& medicinae autoribus', which was printed in Rotmar's volume, ${ }^{47}$ that, regarding anatomy, Vesalius surpasses not only the Arabs but also all the ancients. ${ }^{48}$ And in his introduction to Laurentius Gryll's De sapore

\footnotetext{
${ }^{39}$ Nauck, op. cit., note 38 above, p. 12: "Opiniones inanes, absurdas et noxias, quales multae sunt ex Aristotelis philosophia ortae, ac quaedam ab ipso Galeno passim damnatae, non serio tuebuntur professores."

${ }^{40}$ See L Liess, op. cit., note 23 above, pp. 78-80.

${ }^{41}$ Nauck, op. cit., note 38 above, p. 13.

${ }^{42}$ According to the curriculum, dissections should be performed regularly: "Virorum quoque ac mulierum quotannis unam, aut plures, data occasione, anatomias facient, unanimi consensu professores." (Ibid., p. 13.) The curriculum exemplifies Wear's statement that "a true Galenic
}

anatomy could be critical and progressive", because "Galen himself had written that anatomy could be improved by observation." See Wear, op. cit., note 14 above, p. 272.

${ }^{43} \mathrm{~L}$ Liess, op. cit., note 23 above, p. 87.

${ }^{44}$ See ibid., pp. 131-5.

${ }^{45}$ Ibid., pp. 300-2.

${ }^{46}$ Ibid., p. 301.

${ }^{47}$ Johann Lonaeus Boscius, 'Oratio de optimo medico \& medicinae autoribus', in Rotmar (ed.), op. cit, note 32 above, fol. $268 \mathrm{r}-276 \mathrm{r}$.

${ }^{48}$ Ibid., fol. 275v: “ In anatomia Vesalius non Arabes modo, sed cunctos veteres superavit." 


\section{Jürgen Helm}

dulci et amaro, which was published by Adam Landau in 1566, Landau explicitly singles out Vesalius, Columbus, Valverde and Fallopius, because these anatomists-as he writes-have more than compensated for the shortcomings of the Greeks caused by their lack of human bodies. ${ }^{49}$

In light of these facts I think it not just chance that from 1571 onwards we have records of dissections being performed at the medical faculty. According to Siegfried Hoffmann, the bodies of nine executed criminals were transferred to the faculty to be anatomized between 1571 and $1588 .^{50}$ And in 1576 Duke Albrecht V renewed the order to the municipal council that after an execution the corpse should immediately be delivered to the faculty. ${ }^{51}$ Hence, anatomizing was not only called for, but actively practised in the years after 1571 .

Obviously in Ingolstadt the adoption of Vesalian anatomy was not hindered by the Catholic faith. Landau as well as Boscius were "good Catholics". This is proved not only by the fact that they taught at Ingolstadt for quite a long time (Landau for twelve, Boscius for twenty-seven years), ${ }^{52}$ but also by further evidence. The catalogue of lectures, for example, claims that just as in the faculties of theology and law, so too in the medical faculty a restoration of the old doctrine is necessary to protect medicine against the odd opinions and obvious deceptions of certain modern authors. ${ }^{53}$ The old medicine, which should be striven for and which could counter the attack of the Paracelsians, may-as the text says-properly be called "Catholic medicine". ${ }^{54}$ In opposition to Arno Seifert's objection which rejects a confessional interpretation of "Catholic" in this context, ${ }^{55} \mathrm{I}$ am sure that "Catholic" here refers to nothing else than to the confessional schism in the sixteenth century. This assumption is supported by Landau's oration 'De corruptionis artium causa, \& Antithesi veteris \& novae Medicinae', which was delivered in 1568 and printed in Rotmar's volume. ${ }^{56}$

In his speech Landau establishes-very polemically-a link between Luther's

${ }^{49}$ Adam Landau, 'Epistola dedicatoria', in Laurentius Gryllus, De sapore dulci et amaro, Prague, Melantrich, 1566: "Sed, cum ille [i.e. Galenus] corpora hominum non secuerit, longe plus lucis \& certitudinis huic cognitioni labore \& assiduo studio recentiorum quorundam accessisse. Quod igitur a Graecis olim propter inopiam cadaverum humanorum fuit praetermissum, id Vesalius, Realdus Columbus, Iohannes Valverde, Gabriel Fallopius, \& alii praestantes anatomici tanto cum foenore recompensarunt, ut in hac medicinae parte declaranda nihil propemodum amplius desyderari posse videatur."

${ }^{50}$ Siegfried Hofmann, 'Leichensektionen im 16. Jahrhundert in Ingolstadt', Sammelblatt des Historischen Vereins Ingolstadt, 1974, 83: $284-6$.

${ }^{51}$ L Liess, op. cit., note 23 above, p. 305.

52 See ibid., pp. 139-42.

${ }^{53}$ Ibid., p. 298: "Mirum profecto non est, si non solum in hac celebri schola cum conservanda, tum aliquo modo restauranda theologiae ac iurisprudentiae professores suis praeclarissimis disciplinis optime prospectum cupiant, sed medicinae quoque doctores conspirantibus sententiis in id sedulo incumbant, ut vetustioris solidiorisque medicinae integritas tam contra pravas vulgi opiniones, quam adversus recentiorum quorundam apertas calumnias sarta tectaque asseratur."

${ }^{54}$ Ibid., p. 299: "[Adamus Landavus] qui quicquid iam longo tempore diversis in academiis Germaniae atque Italiae praestantissimorum virorum institutione sibi doctrinae vel experientiae comparavit, id universum discipulis sciendi cupidis optima fide communicaturus est, veteremque medicinam, quam non immerito catholicam appellare licebit, ea semper explicabit industria, ut ... falsitas autem medicinae Paracelsicae principiis quibusdam imaginariis exstructae, constantibus argumentis subversa corruat ...". 195.

${ }^{55}$ Seifert, op. cit., note 15 above, p. 354, n.

${ }^{56}$ Adam Landau, 'Oratio de corruptionis artium causa, \& Antithesi veteris \& novae Medicinae', in Rotmar (ed.), op. cit., note 32 above, fol. $285 \mathrm{r}-299 \mathrm{v}$. 


\section{The Case of Ingolstadt Anatomy}

Reformation and Paracelsus' challenge to the medical world. As Landau argues, Luther was the first to attack traditional teaching in schools and universities and thereby to damage the unity and the context of the sciences. ${ }^{57}$ Landau then describes the negative consequences that Luther's attack had for law, ${ }^{58}$ philosophy, ${ }^{59}$ and medicine. According to Landau, medicine had been given by God to our first parents, and in temporal succession up to Landau's time medicine had become more extensive and more reliable and had been formed into an art. ${ }^{60}$ Hippocrates and Galen, in particular, were involved in this process. ${ }^{61}$ In Landau's view, however, Paracelsus despises this old medicine and places himself outside the tradition. ${ }^{62}$ His confused doctrine is therefore propagated by people whom the religious and public authorities do not permit to teach, and hence it is taught not at the universities, but "in angulis", on street corners. ${ }^{63}$

Two aspects of this oration should be pointed out: first, Landau proves to be a violent anti-Protestant by making Luther responsible for Paracelsianism. For example, in his reasoning there is no attempt to distinguish between Luther's form of Protestantism and radical Protestantism. And second, by connecting Luther and Paracelsus, Landau constructs in fact an opposition between traditional and "Catholic" medicine on the one hand and new and "Protestant" on the other. But this confessional antagonism is not-as French has suggested ${ }^{64}$ — constructed along a line between Galen and Vesalius, but between traditional medicine and Paracelsianism. If, in addition, we consider the evidence for Landau's and Boscius' adoption of Vesalian anatomy, the implications of these findings are obvious: in the view of these Ingolstadt professors, Vesalius was not a reformer who needed to be singled out as one of Luther's adherents intending to shake the foundations of the medical world. On the contrary, he belonged to that traditional medicine which had been given by God and which had been successively improved from the first days of God's world. In other words, Landau's Catholicism does not imply that he was uncritically clinging to ancient authorities like Hippocrates and Galen. As Landau writes in the introduction to Gryll's De sapore, the medical art is too wide to be constructed and perfected by only one human being because human life is short. ${ }^{65}$ Therefore Galen's medicine was completed and corrected in many ways, ${ }^{66}$ and it would be absolutely wrong to devote oneself slavishly to Galen's words. ${ }^{67}$

To summarize, instead of clinging to the ancients, Landau insists on a medical tradition, which he states to be the Catholic one. While Protestantism is claimed to be a threat to this old tradition, Vesalius and other recent anatomists are considered part of Catholic medicine, which has been successively completed and improved from the

\footnotetext{
${ }^{57}$ Ibid., fol. $286 \mathrm{v}-288 \mathrm{r}$.

${ }^{58}$ Ibid., fol. $288 \mathrm{v}-289 \mathrm{r}$.

${ }^{59}$ Ibid., fol. $289 \mathrm{v}$.

${ }^{60}$ Ibid., fol. 291r: "Nam simul ac Deus hanc mundi machinam creavit, singulisque naturis vim qandam indidit, quae vel obesset, vel prodesset hominum generi, eo statim temporis momento medicinam quoque coli et observari voluit, praecepitque primis parentib. ut eam colerent \& exercerent, quae deinceps continuata temporum serie ad nos usque pluribus in locis auctior \& locupletior, \& in artis formam redacta, pervenit."

${ }^{61}$ Ibid.
}

\footnotetext{
${ }^{62}$ Ibid., fol. $291 \mathrm{r}-291 \mathrm{v}$.

${ }^{63}$ Ibid., fol. $295 \mathrm{v}-296 \mathrm{r}$.

${ }^{64}$ See p. 84 above.

${ }^{65}$ Landau, op. cit., note 49 above: "Certe ... ars per se longa ac difficilis ob vitae brevitatem ab uno homine simul inchoari \& perfici nequit."

${ }^{66}$ Ibid.: "Quin etiam res ipsa testatur, post aetatem Galeni medicam artem in pluribus locis non mediocriter auctam, amplificatam \& excultam fuisse."

${ }^{67}$ Landau ridicules certain (unnamed) contemporaries, who "ex Galeno Deum quendam faciunt, qui nunquam erraverit." (Ibid.)
} 


\section{Jürgen Helm}

very beginning. What is striking, however, is the fact that Landau does not worry that exactly the same medical tradition was cultivated in Wittenberg and at several Protestant universities. $^{68}$

Do these findings imply that there is any difference for the students between learning anatomy in Ingolstadt and in Wittenberg? The statutes of the Wittenberg medical faculty, which were set up in 1572, determine that anatomy has to be taught according to the ancients, particularly Galen, and recent authors like Vesalius and Fallopius, who have corrected the mistakes made in previous centuries. ${ }^{69}$ Hence, as far as the authorities consulted in anatomical education are concerned, there was no difference between Wittenberg and Ingolstadt. But, nevertheless, a distinction between Wittenberg and Ingolstadt can be made.

In Wittenberg, anatomy was considered to be part of a Lutheran philosophical education established by Melanchthon during the first half of the century. This integration of anatomy into Protestant thought resulted in an anatomical education, which, in stressing the importance of anatomy for theological reasons, was taught to all students in the arts faculty, based to a large extent on Melanchthon's $D e$ anima. In Ingolstadt, however, anatomy was-as far as the sources suggest-never taught in the faculty of arts. We may assume that around 1550 the teaching on the soul was in accordance with Veit Amerbach's Quatuor libri de anima, ${ }^{70}$ which only incidentally dealt with the human body. Later, when the Jesuits were extending their influence over the arts faculty, anatomical education of the youngest students seems to have been even more unlikely. According to Loyola's Constitutiones, the teaching of medicine should not be performed by members of the Society of Jesus. ${ }^{71}$ Therefore, it is not surprising that in the second half of the century the Ingolstadt discussion of De anima as part of traditional Aristotelian philosophy included only the briefest and most necessary of anatomical details. ${ }^{72}$

The second aspect of Wittenberg anatomy, its conformity in stressing the theological framework of anatomical knowledge, is absent at Ingolstadt as well. This is not to say that at Ingolstadt anatomical education was performed for purely practical

\footnotetext{
${ }^{68}$ As Stefan Rhein showed convincingly, the so-called "Wittenberg Paracelsianism" claimed by Heinrich Haeser and later by Wolfram Kaiser lacks any textual foundation. See Stefan Rhein, 'Melanchthon und Paracelsus', in J Telle (ed.), Parerga Paracelsica. Paracelsus in Vergangenheit und Gegenwart, Stuttgart, Steiner, 1991, pp. 57-73. But this is not to say that sixteenthcentury Protestantism was completely unaffected by Paracelsianism: the rapid spread of Paracelsus' writings and ideas from around 1570 was mainly due to Protestant court physicians, see Wear, op. cit., note 14 above, p. 317, and Hugh TrevorRoper, 'The court physician and Paracelsianism', in V Nutton (ed.), Medicine at the courts of Europe, 1500-1837, London and New York, Routledge, 1990, pp. 79-94.

${ }^{69}$ See Walter Friedensburg (ed.), Urkundenbuch der Universität Wittenberg, Teil 1,
}

1502-1611, Magdeburg, Historische Kommission, 1926, pp. 381-2.

${ }^{70}$ Veit Amerbach, Quatuor libri de anima, Straßburg, Mylius, 1542 (VD 16, A 2229).

${ }^{71}$ G M Pachtler (ed.), Ratio Studiorum et Institutiones Scholasticae Societatis Jesu per Germaniam olim vigentae, Tomus I, Ab anno 1541 ad annum 1599, Osnabrück, Biblio, 1968, p. 54.

${ }^{72}$ See, for example, Christoph Viepekhius, Assertiones de anima, Ingolstadt, Weissenhorn, 1568 (VD 16, V 1002); Albert Hunger, Adversus veteres et novos errores de anima conclusionum centuria, Ingolstadt, Sartorius, 1575 (Resp. Johannes Diettmar) (VD 16, H 5933); Georg Schroetel, Disputatio philosophica, de sensibus internis, Ingolstadt, Eder, 1590 (Resp.: Wilhelm Sixtus Kepser) (VD 16, S 4238). 
reasons, as the 1571 catalogue of lectures might suggest. In this text, anatomy is first and foremost regarded as necessary for surgery, ${ }^{73}$ and something like an overriding philosophical or theological background is definitely not mentioned. On the contrary, there are some texts written by Ingolstadt medical professors which put anatomical knowledge into the wider framework of sixteenth-century theology and philosophy, but these writings do not form such a uniform picture as Wittenberg anatomical texts. Johann Ammonius Agricola, for example, uses anatomy for a moral call on the students to be disciplined and not to hurt each other. In his oration 'De praestantia corporis humani', which was given in 1561 and printed in Rotmar's volume ${ }^{74}$ this appeal is founded on a long excursus on the alleged correspondence of the microcosm of the human body to the macrocosm of the political state. The liver is the Duke, caring for the nourishment and the physical well-being of his subordinates, ${ }^{75}$ the heart distributing the life-giving heat by the spiritus vitalis in the arteries is the Emperor, ${ }^{76}$ and the brain mediating sensation and motion by the spiritus animalis is identified with the Pope ${ }^{77}$ spiritually controlling the whole organism by a triumvirate consisting of "imaginatrix facultas, cogitativa, \& memoratrix" ${ }^{78}$ This wonderful microcosm of the human body proves-as Ammonius says-the Creator's ineffable providence and his immense goodness. ${ }^{79}$ In a similar manner, Cyriacus Lutz (died 1599), who was professor at the medical faculty for twenty-eight years from 1571 , but who spent only eight years at Ingolstadt ${ }^{80}$ emphasizes the importance of medical knowledge for theology in his books. ${ }^{81}$ In this context he mentions Galen's De usu partium, in which contemplation of the human body is claimed to be a guide to knowledge of God's power, wisdom and goodness. ${ }^{82}$

These texts by Ammonius and Lutz, however, remain unique: Ingolstadt anatomy is very far from the uniformity of Lutheran anatomical education performed at Wittenberg University and produced by Melanchthon's power of systemizing. The picture of a certain arbitrariness in Ingolstadt anatomy becomes even more evident when looking at a text that is unexpected in the Catholic context of the University of Ingolstadt.

\footnotetext{
${ }^{73}$ L Liess, op. cit., note 23 above, p. 301 :

"Quae quidem anatomes exercitia et oculis subiectae demonstrationes maximum in arte medica habent usum, potissimum vero frequens illa dissectionum inspectio chirurgicen, (quae ut antiquissima, sic certissima medicinae pars existit) promovet ac illustrat, siquidem eius praecipuum officium versatur in vulnerum, ulcerum,

luxationem, fracturarum, tumorumque sedibus accurate cognoscendis."

${ }^{74}$ Johann Ammonius Agricola, 'De praestantia corporis humani', in Rotmar (ed.), op. cit., note 32 above, fol. 259r-268r.

${ }^{75}$ Ibid., fol. 261r-262v.

${ }^{76}$ Ibid., fol. $263 \mathrm{r}-263 \mathrm{v}$.

${ }^{77}$ Ibid., fol. 264v-265r.

${ }^{78}$ Ibid., fol. $265 \mathrm{v}$.

${ }^{79}$ Ibid., fol. 266v.

${ }^{80}$ About Lutz, see L Liess, op. cit., note 23 above, pp. 145-6.
}

\footnotetext{
${ }^{81}$ See, for example, Cyriacus Lucius, De medicina philosophica, Ingolstadt, Eder, 1597 (VD 16, L 7655), pp. 9-10, 21-2, 36-7; idem, De considerando praesenti christianae reipub. statu, et academiarum officio, Ingolstadt, Sartorius, 1589 (VD 16, L 7650), pp. 21-2.

${ }^{82}$ Ibid., p. 22: "Circa usum non est ignorandum aut negligendum, quod scientia Medica non solum curae valetudinis corporeae in Repub. instituendae, sed \& aliis scientiis addiscendis \& docendis, ipsique $\mathrm{S}$. Theologiae utilis esse queat; atque hoc (ut alia argumenta gravia nunc taceam) ex ipso Galeno clarissime pateat. Galenus enim Medicos libros de usu partium corporis humani exacte scribens, in opificis admirationem, \& laudem ipsi dicendam saepius effertur; in Deo, potentiam, sapientiam, \& bonitatem summam esse agnoscit, \& mire praedicat ...".
} 


\section{Melchior Fleck's 'Oratio de praestantia corporis humani'}

Valentin Rotmar's volume of orations by Ingolstadt doctors and professors includes two texts entitled 'De praestantia corporis humani'. The first is the speech by Ammonius comparing the human body with the public state, ultimately controlled by the Pontifex maximus. The other is an oration given by a certain Melchior Fleck on the occasion of his own graduation as doctor of the medical faculty in January $1568 .^{83}$ Given the intellectual background of this text, it is amazing that it was printed in Rotmar's book, which was intended to show the academic virtues and strength of the Catholic University of Ingolstadt. Melchior Fleck's speech could not have been better delivered at Wittenberg University. Nearly all the topoi of Melanchthon's view on human anatomy are here collected together, beginning with the need for anatomical knowledge on the part of all students ${ }^{84}$ and ending with the twofold government, the despotical and the political, exercised by human reason over the locomotive faculty and the heart with its affections respectively. ${ }^{85}$ Instead of showing step by step the origin of this text in Melanchthon's textbooks and declamations, I would like to prove the text's Wittenberg provenance from only a few examples. In part these quotations correspond literally to Melanchthon's Liber de anima (Table 1).

Who was Melchior Fleck, the author of this Wittenberg text expounded at Ingolstadt? According to the Matricula of the University the "student of medicine Magister Melchior Fleck from Triptis" came to Ingolstadt in November $1566 .{ }^{86}$ And according to the Annales of the University, which were initiated by Valentin Rotmar, he attained his doctorate in 1568 together with Georg Palma, whom we have already encountered. As the Annales say, Fleck was then working as a physician at Salzburg "non sine laude". ${ }^{87}$ Unfortunately, the standard biographical handbooks and reference books do not yield further information. But considering the "Melanchthonian character" of his oration given at Ingolstadt and bearing in mind that he is reported to come from Triptis, a town in Thüringia, it is hardly surprising that Melchior Fleck is listed in the Matricula of the University of Jena. He attended this University from 1555, graduated in 1564 and became a member of the faculty of arts in $1565 .{ }^{88}$ There is no doubt that it was at the University of Jena, where Johann Stigel (1515-1562) taught at the arts faculty until his death in 1562, that Fleck came into contact with the Wittenberg approach to

\footnotetext{
${ }^{83}$ Melchior Fleckh, 'Oratio de praestantia corporis humani', in Rotmar (ed.), op. cit., note 32 above, fol. $324 r-334 r$.

${ }^{84}$ Ibid., fol. 325 r.

${ }^{85}$ Ibid., fol. 333r-333v; cf. Melanchthon, op. cit., note 6 above, col. 129-30.

${ }^{86}$ Götz Freiherr von Pölnitz, Die Matrikel der Ludwig-Maximilians-Universität IngolstadtLandshut-München, Teil I, Ingolstadt, Band I, 1472-1600, Munich, Lindauer, 1937, p. 891: "Melchior Fleck Triptizensis magister et medicinae studiosus."

${ }^{87}$ Johann Nepomuk Mederer, Annales Ingolstadiensis Academiae. Inchoarunt Valentinus
} 
Table 1

Some correspondences between Fleck's oration and Melanchthon's Liber de anima

\begin{tabular}{|c|c|}
\hline $\begin{array}{l}\text { M Fleck, } \\
\text { Oratio de praestantia corporis humani, } 1568\end{array}$ & $\begin{array}{l}\text { Ph. Melanchthon, } \\
\text { Liber de anima, } 1553 \text { (CR 13) }\end{array}$ \\
\hline $\begin{array}{l}\text { Soleo mihi saepe ante oculos proponere } \\
\text { pulcherrima mundi corpora, coelum, stellas, } \\
\text { elementa, metalla, gemmas, plantas, } \\
\text { animantia, ut hanc sententiam animo meo } \\
\text { penitus infigam, naturam non extitisse casu, } \\
\text { sed a mente architectatrice constitutam et } \\
\text { ordinatam esse. (Fol. 326r.) }\end{array}$ & $\begin{array}{l}\text { Etsi totius naturae, coeli, elementorum. } \\
\text { plantarum, metallorum et animantium } \\
\text { fabricatio plurima continet miracula, et } \\
\text { illustria testimonia, quae ostendunt, hanc } \\
\text { naturam non extitisse casu, sed a mente } \\
\text { architectatrice conditam et ordinatam esse. } \\
\text { (Col. 65-6.) }\end{array}$ \\
\hline $\begin{array}{l}\text { [cerebrum] sapientiae domicilium est, } \& \\
\text { officina cogitationum, iudicii, } \\
\text { ratiocinationis, memoriae, quibus Deo } \\
\text { genus humanum sit similimum. (Fol. } 327 \mathrm{v} \text {.) }\end{array}$ & $\begin{array}{l}\text { [cerebrum] quod est domicilium sapientiae } \\
\text { et Deo similimum, ac officina est } \\
\text { cogitationum, iudicii, ratiocinationis, et } \\
\text { memoriae, ... (Col. } 69 \text {.) }\end{array}$ \\
\hline \multirow{2}{*}{$\begin{array}{l}\text { Sed quae est substantia cerebri? ubi \& } \\
\text { quomodo fiunt in hac tam squalida massa } \\
\text { actiones tam admirandae? Haec fateri nos } \\
\text { est necesse, non penitus sciri, sed quantum } \\
\text { tamen sciri possunt, \& consideremus, \& } \\
\text { grati celebremus. Agnoscamus etiam esse } \\
\text { Deum mentem aeternam, architectatricem, } \\
\text { quae organa corporis ad actiones diversas } \\
\text { tanta arte \& sapientia fabricavit, \& eandem } \\
\text { esse veracem, beneficam, iustam, castam, } \\
\text { liberrimae voluntatis, qualem sese expressit } \\
\text { iis notitiis, quas radiis suae sapientiae in } \\
\text { mentibus nostris accendit. (Fol. 328v.) }\end{array}$} & $\begin{array}{l}\text { Praeterea quae est substantia cerebri? ubi? } \\
\text { quomodo fiunt hae mirandae actiones in } \\
\text { hac squalida massa? Haec fateamur non } \\
\text { penitus sciri, et agnoscamus Deum esse } \\
\text { naturae nostrae conditorem, et actiones } \\
\text { cerebri poprias maxime testari, hunc } \\
\text { mundum non extitisse casu, et Deum } \\
\text { conditorem esse mentem sapientem, } \\
\text { beneficam, iustam et veracem. (Col. } 69 .)\end{array}$ \\
\hline & $\begin{array}{l}\text { Talis est igitur Deus, ut hunc ordinem velit, } \\
\text { et hae noticiae radii sunt sapientiae divinae. } \\
\text { (Col. 138.) }\end{array}$ \\
\hline $\begin{array}{l}\text { Sed inter omnes partes consideratione } \\
\text { dignissima est copulatio arctissima venarum } \\
\text { et arteriarum. Nam in toto corpore venis } \\
\text { adiunctae sunt arteriae, propter } \\
\text { communicationem officiorum. Ut enim } \\
\text { venae suppeditant spiritui materiam, unde } \\
\text { nutriatur, sic spiritus in arteriis calore suo } \\
\text { fovet sanguinem; quae quidem imago } \\
\text { congruit ad multa, quae Deus vult esse } \\
\text { consociata. (Fol. 330v.) }\end{array}$ & $\begin{array}{l}\text { Ac iucundum est considerare consensum } \\
\text { venarum et arteriarum, et mutua officia. } \\
\text { Nam arteriae venis adiunctis per } \\
\text { angustissimos poros ac meatus impertiunt } \\
\text { spiritum, qui calore vitali sanguinem } \\
\text { exuscitat, percoquit et conservat. Rursus } \\
\text { etiam arteriae hauriunt aliquantulum } \\
\text { sanguinis ex venis, quo vehitur, rigatur et } \\
\text { augetur spiritus. . . Illustre autem } \\
\text { exemplum nobis in hac imagine propositum } \\
\text { est mutuae communicationis, sine qua } \\
\text { conservari natura non potest. (Col. 55.) }\end{array}$ \\
\hline
\end{tabular}




\section{Jürgen Helm}

anatomy. Johann Stigel was one of Melanchthon's famous disciples, ${ }^{89}$ and it is well known that Stigel was familiar with Melanchthon's De anima. His poem De utilitate doctrinae de fabricatione humani corporis was printed in the appendix to the Liber de anima ${ }^{90}$ and his Explicatio on Melanchthon's De anima was published for the first time eight years after his death in $1570 . .^{91}$

Melchior Fleck's speech confirms the diversity of approaches to anatomical education at Ingolstadt. I do not think that the provenance of the text was known to Valentin Rotmar, who adopted it in his volume and who judged it to be "non inelegans" in the Annales. ${ }^{92}$ For the historian, however, it is almost amusing to find Melanchthon's ideas and words next to Ammonius' glorification of papal power and next to Landau's polemic against a Paracelsianism supposed to be induced by the Protestants. But what is more important, it shows that the substance of Melanchthon's reading of De anima could be taught at a Catholic university as well. Obviously, Melanchthon's views on anatomy were not considered specifically Lutheran by the Catholic teachers at Ingolstadt.

\section{Conclusion}

The substance of Ingolstadt anatomy has been shown to be similar to that at Wittenberg. There is strong evidence that-at least from 1571-recent anatomical literature was easily adopted by the Ingolstadt professors. Hence, in their attitude to anatomy, the Catholics at Ingolstadt were no more conservative than their Protestant colleagues at Wittenberg.

But this is not to say that religious confession did not influence medical education. At Ingolstadt, Protestantism was suspected of having produced Paracelsianism, which was located outside the old medical tradition. This tradition, "Catholic" medicine, as it was called, had begun with God's creation and had been successively improved. In the view of the Ingolstadt teachers, Vesalius and the other modern anatomists had not broken with this Catholic medicine but were even considered part of this old tradition. Likewise, Melanchthon's Liber de anima proves that in Wittenberg, too, Vesalius' Fabrica was not perceived as a medical revolution, but as an appropriate correction of Galen, whose work still formed the foundation for anatomical and medical knowledge. ${ }^{93}$

In its theological and philosophical background, Ingolstadt anatomy was far less uniform than anatomical education at Wittenberg. With a variety of different philosophical approaches this arbitrariness produced the odd result that by way of Melchior Fleck's speech the "coherent message of Lutheran anatomists", that Nutton described, ${ }^{94}$ was also heard at the Catholic University of Ingolstadt.

\footnotetext{
${ }^{89}$ See Stefan Rhein, 'Johannes Stigel (1515-1562). Dichtung im Umkreis

Melanchthons', in Scheible (ed.), op. cit., note 22 above, pp. $31-48$. 232.

${ }^{90}$ See Cunningham, op. cit., note 2 above, $\mathrm{p}$.

${ }^{91}$ Johannes Stigelius, De anima commentarii clarissimi atque doctissimi viri D. Philippi
}

Melanchthonis explicatio, Mühlhausen, Hantzsch, 1570 (VD 16, M 2772). See Schüling, op. cit., note 6 above, p. 242.

${ }_{92}$ See note 87 above.

${ }^{93}$ See Jürgen Helm, 'Die Galenrezeption in Philipp Melanchthons De anima (1540/1552)', Medizinhist. J., 1996, 31: 298-321, on pp. 317-20.

${ }^{94}$ See p. 84 above. 